\title{
Formulation and Standardization of Polyherbal Antihyperlipidemic Formulation
}

\author{
Smitha Rani ${ }^{1}$ and S. L. Manju ${ }^{2 *}$ \\ 'Department of Chemistry, VIT University, Vellore - 632014,Tamil Nadu, India; ranismi@gmail.com \\ ${ }^{2}$ Department of Chemistry, School of Advanced Sciences, VIT University, Vellore - 632014, \\ Tamil Nadu, India; sImanju@vit.ac.in
}

\begin{abstract}
Hyperlipidemia is a very common medical condition. A fairly less invasive, more effective and efficient method with lower or no side effects to treat Hyperlipidemia are to be developed. Thus, use of traditional herbal medication can be a relevant solution to it. Development of highly standardized Polyherbal formulation with respect to chemical content and therapeutic activity is considered as a valuable approach in the field of herbal industry. Traditional medicine is known for its Polyherbal contents and multicomponent therapeutics for managing health problems. Thus, the present research is focused on to formulate, standardize a polyherbal medicine to treat hyperlipidemia and also compared its chemical contents based on, geographical, seasonal variations using standard physio-chemical parameters such as Ash values, Extractive values, $\mathrm{pH}$, and loss on drying, Particle size analysis and physical analysis of powder formulation. HPTLC fingerprinting, with markers such as Gallic acid, Quercetin, Gymnemic acid, and Mahanine were carried out. In addition, residue analysis such as heavy metal content, microbial load, pesticide analysis, aflotoxin determination were also carried out to strengthen the standardization process and to ensure safety.
\end{abstract}

Keywords: Antihyperlipidemic, HPTLC Profiling, Physico-chemical Parameters, Polyherbal, Standardization

\section{Introduction}

\subsection{Hyperlipidemia and its Impact}

Health care professionals are anxious about hyperlipidemia because of the strong association of lipid concentrations and the risk of cardio vascular diseases. Such incidences have been reported to be a major cause of deaths globally ${ }^{1}$. As per a study, "Hyperlipidemia is a medical condition characterized by an increase in one or more of the plasma lipids, including triglycerides, cholesterol, cholesterol esters, phospholipids and or plasma lipoproteins including very low-density lipoprotein and low-density lipoprotein along with reduced high-density lipoprotein levels" ${ }^{2}$. In simple words, hyperlipidemia is a medical condition wherein the level of lipids (fats) is higher in blood which is a state of high cholesterol.

Hyperlipidemia is a wider term which encompasses any of the numerous genetic or acquired conditions that lead to a high level of lipids (like cholesterol triglycerides and fats) circulating in the blood. These lipids can pass through the walls of arteries. Such entry increases the danger of hardening of the arteries (atherosclerosis), which can result in heart attack, stroke and also amputation. The effect of cholesterol level in blood is explained in Table 1.

Hyperlipidemia is a very common medical condition. More than 3 million people in Europe United States alone have this genetic disorder ${ }^{4}$. Hyperlipidemia is usually chronic, and can be controlled by continuous medication for maintaining the blood lipid levels. In

*Author for correspondence

Article Received on: 19.01.2020

Revised on: 02.09.2020

Accepted on: 10.12.2020 
Table 1. Effects of the level of cholesterol ${ }^{3}$

\begin{tabular}{|c|c|}
\hline Total level of cholesterol & Category \\
\hline $\begin{array}{l}\text { Less than } 190 \mathrm{mg} / \mathrm{dl} \\
\text { Desirable }\end{array}$ & $\begin{array}{l}\text { Less than } 190 \mathrm{mg} / \mathrm{dl} \\
\text { Desirable }\end{array}$ \\
\hline 200-240 mg/dl Borderline & 200-240 mg/dl Borderline \\
\hline Above 240 mg/dl High & Above $240 \mathrm{mg} / \mathrm{dl} \mathrm{High}$ \\
\hline $\begin{array}{l}\text { LDL (Bad) level of } \\
\text { cholesterol LDL category }\end{array}$ & $\begin{array}{l}\text { LDL (Bad) level of } \\
\text { cholesterol LDL category }\end{array}$ \\
\hline Less than $98 \mathrm{mg} / \mathrm{dl}$ Optimal & $\begin{array}{l}\text { Less than } 98 \mathrm{mg} / \mathrm{dl} \\
\text { Optimal }\end{array}$ \\
\hline $\begin{array}{l}98-130 \mathrm{mg} / \mathrm{dl} \text { Above } \\
\text { optimal }\end{array}$ & $\begin{array}{l}\text { 98-130 mg/dl Above } \\
\text { optimal }\end{array}$ \\
\hline 131-159 mg/dl Borderline & 131-159 mg/dl Borderline \\
\hline 160-190 mg/dl High & 160-190 mg/dl High \\
\hline Above 190 mg/dl Very high & Above $190 \mathrm{mg} / \mathrm{dl}$ Very high \\
\hline $\begin{array}{l}\text { HDL (Good) level of } \\
\text { cholesterol HDL category }\end{array}$ & $\begin{array}{l}\text { HDL (Good) level of } \\
\text { cholesterol HDL category }\end{array}$ \\
\hline $\begin{array}{l}\text { Less than } 39 \mathrm{mg} / \mathrm{dl} \text { Major } \\
\text { risk for heart }\end{array}$ & $\begin{array}{l}\text { Less than } 39 \mathrm{mg} / \mathrm{dl} \text { Major } \\
\text { risk for heart }\end{array}$ \\
\hline 39-59 mg/dl Better & $39-59$ mg/dl Better \\
\hline $\begin{array}{l}\text { Above } 60 \mathrm{mg} / \mathrm{dl} \text { Protective } \\
\text { against heart disease }\end{array}$ & $\begin{array}{l}\text { Above } 60 \mathrm{mg} / \mathrm{dl} \text { Protective } \\
\text { against heart disease }\end{array}$ \\
\hline
\end{tabular}

case, it is not treated timely, it can take the form of a serious illness and many a times turns out to be life threatening.

\subsection{Existing Antilipidemic Formulations}

The majority of approaches available in market today for reduction of lipids are based on practices like disturbing the enterohepatic circulation of bile acids, lowering the levels of LDL-C by disrupting cholesterol biosynthesis, or disruption of intestinal cholesterol absorption $^{5}$.

The cure of hyperlipidemia disorders was transformed with the use of statins as a treatment drug. It has become the most significant therapeutic option at present to reduce and prevent its damaging consequences of hyperlipidemia like cardiovascular diseases, when compared with other drugs ${ }^{6}$. With improvement in decreasing the elevated Low Density Lipoprotein (LDL) levels with statins, the risk for CVDs can be reduced by $30 \%$ thereby leaving behind a remaining risk of $70 \%$ for the development and advancement of $\mathrm{CVD}^{5}$. This presents a high medical requirement for more efficient Antilipidemic medicine. To deal with this situation, many new approaches and treatments are being developed to lower this gap of $70 \%$. Some of these prominent approaches are Apo lipoprotein B and LDL-Depressing ${ }^{7-9}$, Therapeutic Proteins and increasing High-density Lipoprotein $(\mathrm{HDL})^{10-12}$.

Till the time the clinical trials are in process and reduction in the side effects of above drugs is in process, a fairly less invasive, more effective and efficient with lower or no side effect drug has to be developed.

\subsection{Importance of Polyherbal Formulations}

There are two basic principles in Ayurveda on which drug formulation is based. The first one being using a single drug and second one uses more than one drug ${ }^{13}$. The use of more than one drug is called polyherbal. This chief therapeutic herbal strategy is traditional and combines different medicinal herbs to attain extra therapeutic effectiveness called polyherbalism. The increasing popularity of polyherbal drugs lies in the fact that these drugs facilitate in achieving improved therapeutic efficacy. The importance of polyherbal medicine lies in the fact that active phytochemical constituents of single plants are insufficient to reach the desirable therapeutic effects. When polyherbal formulations combine the multiple herbs in a careful ratio, it will give an enhanced therapeutic effect and decrease the toxicity. The active constituents used from individual plants are inadequate to provide attractive pharmacological action.

\subsection{Importance of Standardization of Herbal Medicine}

India is a country where around 25,000 medicinal plant species have been documented. Out of these around 800-900 plant species are used by more than 500 traditional communities for curing different diseases. At global level as well, over the past three decades, the use of herbal medicinal products and supplements has increased greatly. Around $80 \%$ of people globally rely on herbal medicines for a portion of primary healthcare ${ }^{14}$. Even though, such a huge number 
of people dedicatedly use herbal and polyherbal medicines, their standardization is limited and field is less explored. The understanding of the mode of action of polyherbal medicines, potential hostile reactions, contraindications and interactions with existing conventional medicines and foods to endorse safe and sensible usage of these agents is still less explored. The increasing use of botanicals by the public is compelling the researchers to evaluate the impact of such medicines and to devise usage standards, side-effects and quality.

\subsection{Objectives of the Study}

Hyperlipidemia is a predominant disease. It is a chief constituent of the metabolic syndromes like stroke, type 2 diabetes and heart diseases. This disease escalates ill health and mortality in combination with other diseases like hypertension, diabetes mellitus, and cardiovascular diseases. The side effects of the available lipid-lowering medicines have augmented the inclination to adopt traditional treatments involving herbs over conventional drugs. Time and again, various epidemiological studies and observations show that consumption of medicinal plants has had acceptable outcomes on reducing the effects of hyperlipidemia in different societies. Many a times, 1-disease, 1-drug and 1-target mode is not sufficient to cure some complex conditions like hyperlipidemia. So, the treatment plan has been shifted to multi- drug formats like polyherbal medicines. Thus, the present research work is focused on introduce and standardize a polyherbal medicine for treating hyperlipidemia. Further the study will also compare the impact of seasonal variations on chemical contents of ingredient herbs of polyherbal medicine.

\section{Materials and Methods}

\subsection{Selection and Description of Formulation}

The present research has been conducted on a traditional polyherbal formulation for treatment of hyperlipidemia. The medicine is prepared and dispensed by traditional Vaidyas of Malappuram district of Kerala, India. The ingredients used in the preparation of the polyherbalformulation are as follows-
- Indian gooseberry or Amla fruit (Phyllanthus emblica)

- Gymnema leaves (Gymnema sylvestre)

- Acacia bark (Acacia catechu)

- Curry leaves (Murraya koenigii)

The above four ingredients are dried, mixed in the ratio of 1:1:1:1 and finely powdered (churna). The patients suffering from hyperlipidemia are advised to consume $20 \mathrm{~g}$ of this powder daily with warm water.

\subsection{Collection of Ingredients}

Ingredients of polyherbal formulation have been collected from Malappuram dist. Kerala, and Nilagiri district of Tamil Nadu, India. The ingredients have been collected during two different seasons, and in two different geographical conditions. This has been done to test the potential of the polyherbal formulation prepared from the ingredients collected in different seasons and geographies stated as follows:

PHF 1-Ingredients collected from Malappuram, Kerala, during summer season (March-April)

PHF 2-Ingredients collected from Malappuram, Kerala, during monsoon season (July-August)

PHF 3-Ingredients collected from Gudallore, Nilagiri district of Tamil Nadu, during summer season (March-April)

PHF 4-Ingredients collected from Gudallore, Nilagiri district of Tamil Nadu, during Monsoon season (July-August)

The authentication of the collected ingredients has been done by Dr. Sreekala, Senior Scientist, Drug Standardization Division, Arya Vaidya Sala Kottakkal, Centre for Medicinal Plant Research, Malappuram district, Kerala, India.

\subsection{Preparation of Formulation}

The collected ingredients are shade dried and powdered separately. Further, they are passed through 80 mesh size sieve and are mixed in 1:1:1:1 ratio. The powdered polyherbal formulation is then stored in air tight container. The powdered formulations are prescribed because of their smaller particle size. The smaller the particle size, the greater is its absorption rate in GIT (gastrointestinal tract) ${ }^{15}$. 
Table 2. Estimation of markers in four formulations

\begin{tabular}{|c|c|c|c|c|c|}
\hline \multirow[b]{2}{*}{ Marker } & \multirow{2}{*}{$\begin{array}{c}\text { Standard } \\
\text { preparations }\end{array}$} & \multirow[b]{2}{*}{ Preparation of Test } & \multicolumn{2}{|c|}{ Chromatographic condition } & \multirow[b]{2}{*}{ Procedure } \\
\hline & & & $\begin{array}{c}\text { Stationary } \\
\text { phase }\end{array}$ & Mobile phase & \\
\hline $\begin{array}{c}\text { Gallic } \\
\text { Acid and } \\
\text { Quercetin }\end{array}$ & $\begin{array}{c}\text { Prepared by } \\
\text { dissolving } \\
10 \mathrm{mg} \text { Gallic } \\
\text { acid in } 10 \mathrm{ml} \\
\text { of methanol } \\
\text { and } 10 \mathrm{mg} \text { of } \\
\text { Quercetin in } 10 \\
\text { ml of methanol } \\
\text { respectively i.e. } \\
1 \mathrm{mg} / \mathrm{ml}^{36}\end{array}$ & $\begin{array}{c}\text { Polyherbal formulations (F1, } \\
\text { F2, F3 and F4) were extracted } \\
\text { in hydro-alcoholic solutions, } \\
\text { dried and concentrated } \\
\text { under vacuum. About } 100 \\
\text { mg of formulations (F1, F2, } \\
\text { F3 and F4) were dissolved in } \\
5 \mathrm{ml} \text { of hydro-alcohol solution } \\
\text { each }\end{array}$ & $\begin{array}{c}\text { Silica Gel } 60 \\
\text { F } 254\end{array}$ & $\begin{array}{c}\text { Toluene: } \\
\text { Ethyl Acetate: } \\
\text { Formic acid } \\
(5: 4: 1)\end{array}$ & $\begin{array}{l}\text { Apply } 5 \mu \text { of standard } \\
\text { solutions and } 5,10 \mu \text { of } \\
\text { test solutions spotted on } \\
\text { a pre-coated silica gel } 60 \\
\text { F254 HPTLC plate (E. Merck) } \\
\text { of uniform thickness } 0.2 \mathrm{~mm} \\
\text { using Linomat5 sample } \\
\text { applicator. Development } \\
\text { distance of } 8 \mathrm{~cm} \text {. Observed } \\
\text { under UV light at 254nm } \\
\& 366 \mathrm{~nm} \text { using CAMAG } \\
\text { REPROSTAR3 }\end{array}$ \\
\hline $\begin{array}{c}\text { Gymnemic } \\
\text { Acid }\end{array}$ & $\begin{array}{c}\text { Procured } \\
\text { from Natural } \\
\text { Remedies Pvt. } \\
\text { Ltd. Bangalore, } \\
\text { India.About } \\
1 \mathrm{mg} \text { of } \\
\text { Gymnemic acid } \\
\text { was dissolved } \\
\text { in } 1 \mathrm{ml} \text { of } \\
\text { methanol. }\end{array}$ & $\begin{array}{l}\text { Test Solution: About } 2 \mathrm{~g} \text { of } \\
\text { samples were refluxed with } \\
\mathrm{n} \text {-hexane, filter discard the } \\
\text { hexane extract. Reflux the } \\
\text { dried marc with } 50 \% \text { ethanol } \\
\text { at } 60^{\circ} \mathrm{C} \text { for } 1 \mathrm{~h} \text {, cool and filter. } \\
\text { To the aqueous ethanolic } \\
\text { extract add } 10 \% \text { hydrochloric } \\
\text { acid until the precipitation } \\
\text { is complete, collect the } \\
\text { precipitates. Dissolve } 10 \mathrm{mg} \\
\text { of the precipitate in } 1 \mathrm{ml} \\
\text { of ethanol and use for TLC } \\
\text { profiling. }\end{array}$ & $\begin{array}{c}\text { Silica Gel } 60 \\
\text { F254. }\end{array}$ & $\begin{array}{c}\text { n-Butanol: } \\
\text { Ethanol: Water } \\
(10: 1: 1) \\
\text { S1- } 10 \mu \text { l of } \\
\text { Standard } \\
\text { Gymnemic } \\
\text { acid, T1-T4- } \\
20 \mu \text { of test } \\
\text { solution of } \\
\text { sample } 1 \text { to } 4\end{array}$ & -- \\
\hline Mahanine & $\begin{array}{c}\text { Procured } \\
\text { from Natural } \\
\text { Remedies Pvt. } \\
\text { Ltd., Bangalore. } \\
\text { About } 1 \mathrm{mg} \text { of } \\
\text { mahanine was } \\
\text { dissolved in } 1 \mathrm{ml} \\
\text { of methanol }^{37}\end{array}$ & $\begin{array}{l}5 \mathrm{gm} \text { of sample dissolved in } \\
100 \mathrm{ml} \text { ether alcohol mixture } \\
(80: 20) \text { followed by } 2 \mathrm{ml} \text { of } \\
\text { dilute ammonia solution. } \\
\text { Allow to stand for } 1 \text { hour, to } \\
\text { the filtrate add } 30 \mathrm{ml} \text { of } 1 \mathrm{~N} \\
\text { sulphuric acid, separate the } \\
\text { acid layer. To the remaining } \\
\text { ether alcoholic mixture was } \\
\text { extracted with alcoholic } \\
0.5 \mathrm{~N} \text { sulphuric acid ( } 3: 1) \\
\text { (5x25ml) and separated the } \\
\text { acid layer. Further combined } \\
\text { acid layer was extracted with } \\
\text { chloroform. Then acid layer } \\
\text { was adjusted to pH } 10 \text { with } \\
\text { ammonia. Then mixture was } \\
\text { extracted with chloroform } \\
\text { until the sample free from } \\
\text { alkaloids. The collected } \\
\text { chloroform layer was } \\
\text { evaporated to dryness. The } \\
\text { dried residue was dissolved } \\
\text { in methanol was used for TLC } \\
\text { analysis. }\end{array}$ & $\begin{array}{l}\text { Silica Gel } 60 \\
\text { F254 }\end{array}$ & 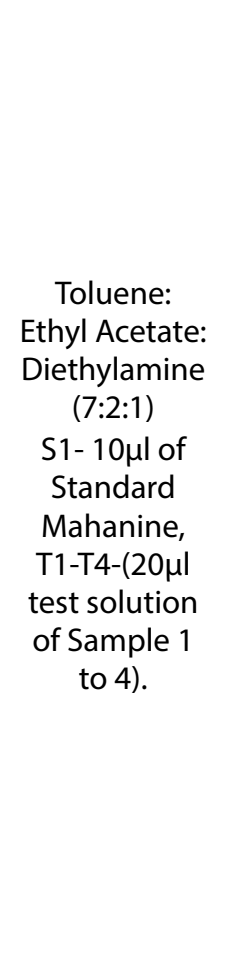 & $\begin{array}{l}\text { Applied } 10 \mu \text { of standard } \\
\text { solution and } 20 \mu \text { l of test } \\
\text { solutions on a precoated } \\
\text { silica gel } 60 \text { F254 HPTLC } \\
\text { plate (E. Merck) of uniform } \\
\text { thickness } 0.2 \mathrm{~mm} \text { using } \\
\text { Linomat5 sample applicator. } \\
\text { Developed the plate in the } \\
\text { solvent system to a distance } \\
\text { of } 8 \mathrm{~cm} . S c a n n e d \text { the plate } \\
\text { densitometrically at } 254 \mathrm{~nm} \\
\text { using TLC Scanner3. } \\
\text { Observed the plate under } \\
\text { UV light at } 254 \mathrm{~nm} \& 366 \mathrm{~nm} \\
\text { using CAMAG REPROSTAR3 }\end{array}$ \\
\hline
\end{tabular}




\subsection{Testing Physicochemical Parameters}

Different physicochemical parameters considered are as follows-

1. Ash Value: Ash is the inorganic residue left behind after removal of organic matter and water by heating. This facilitates in measuring the total amount of minerals within the drug ${ }^{16}$. Measuring ash value is necessary since the mineral matter may be the reason of a pharmacological consequence. The ash value has been determined on the basis of following aspects. Ash values have been determined as per Ayurvedic Pharmacopoeia of India (API). The results have been tabulated in Tables 3, 4 and 5 .

2. Extractive Value: It is the quantity of active constituents in a given amount of plant material when extracted with a particular solvent ${ }^{16}$. Herein the crude drug can be exhausted or not. Following extractive values have been taken into consideration. The results have been tabulated in Tables 6 and 7 .

3. Moisture Content: Moisture content in drug leads to microbial growth. It can instigate the presence of insects or fungi in formulations. Thus, moisture content should be controlled. Herein, the loss on drying was conducted at $105^{\circ} \mathrm{C}$. The results are tabulated in Table 8.

4. Determination of $\mathbf{p H}: \mathrm{pH}$ is used to analyse the acidic and basic aspects of drug ${ }^{17}$. Herein, evaluation of $\mathrm{pH}$ for $1 \% \mathrm{w} / \mathrm{v}$ and $10 \% \mathrm{w} / \mathrm{v}$ of aqueous solution were carried out in triplicate values. The results have been tabulated in Table 9.

Table 3. Total ash values

\begin{tabular}{ccc}
\hline Formulation & Total ash & Standard as per API \\
\hline PHF 1 & $8.03 \pm 0.03$ & \\
PHF 2 & $8.03 \pm 0.03$ & Not more than $11 \%$ \\
PHF 3 & $8.11 \pm 0.05$ & \\
PHF 4 & $8.07 \pm 0.03$ & \\
\hline
\end{tabular}

Table 4. Acid insoluble ash value

\begin{tabular}{ccc}
\hline Formulation & $\begin{array}{c}\text { Acid insoluble } \\
\text { Ash }\end{array}$ & $\begin{array}{c}\text { Standard as per } \\
\text { API }\end{array}$ \\
\hline PHF 1 & $2.52 \pm 0.03$ & \\
PHF 2 & $2.56 \pm 0.04$ & Not less than 1\% \\
PHF 3 & $2.55 \pm 0.53$ & \\
PHF 4 & $2.59 \pm 0.03$ & \\
\hline
\end{tabular}

Table 5. Water soluble ash value

\begin{tabular}{ccc}
\hline Formulation & Water Soluble Ash & $\begin{array}{c}\text { Standard as per } \\
\text { API }\end{array}$ \\
\hline PHF 1 & $2.52 \pm 0.03$ & \\
PHF 2 & $2.56 \pm 0.04$ & Not mentioned \\
PHF 3 & $2.55 \pm 0.53$ & \\
PHF 4 & $2.59 \pm 0.03$ & \\
\hline
\end{tabular}

Table 6. Water soluble extractive values

\begin{tabular}{ccc}
\hline Formulations & $\begin{array}{c}\text { Water soluble } \\
\text { Extractive Values }\end{array}$ & $\begin{array}{c}\text { Standard as per } \\
\text { API }\end{array}$ \\
\hline PHF 1 & $9.34 \pm 0.03 \%$ & \\
PHF 2 & $9.01 \pm 0.04 \%$ & Not less than 22\% \\
PHF 3 & $9.45 \pm 0.04 \%$ & \\
PHF 4 & $9.87 \pm 0.04 \%$ & \\
\hline
\end{tabular}

Table 7. Acid soluble extractive values

\begin{tabular}{ccc}
\hline Formulations & $\begin{array}{c}\text { Alcohol Soluble } \\
\text { Extractive Values }\end{array}$ & $\begin{array}{c}\text { Standard as per } \\
\text { API }\end{array}$ \\
\hline PHF 1 & $9.34 \pm 0.03 \%$ & \\
PHF 2 & $9.01 \pm 0.04 \%$ & Not less than \\
PHF 3 & $9.45 \pm 0.04 \%$ & $13 \%$ \\
PHF 4 & $9.87 \pm 0.04 \%$ & \\
\hline
\end{tabular}

Table 8. Moisture content

\begin{tabular}{ccc}
\hline Formulations & Moisture Content & $\begin{array}{c}\text { Standard as per } \\
\text { API }\end{array}$ \\
\hline PHF 1 & $0.102 \pm 0.001$ & \\
PHF 2 & $0.106 \pm 0.001$ & Not more than \\
PHF 3 & $0.103 \pm 0.001$ & $10 \%$ \\
PHF 4 & $0.105 \pm 0.001$ & \\
\hline
\end{tabular}

Table 9. $\mathrm{pH}$ values

\begin{tabular}{cccc}
\hline Formulations & $\mathbf{p H}(1 \%)$ & $\mathbf{p H}(10 \%)$ & $\begin{array}{c}\text { Standard as per } \\
\text { API }\end{array}$ \\
\hline PHF 1 & 5.4 & 5.4 & \\
PHF 2 & 5.2 & 5.2 & Not mentioned \\
PHF 3 & 5.1 & 5.1 & \\
PHF 2 & 5.2 & 5.2 & \\
\hline
\end{tabular}

$\mathrm{pH}$ values show the formulations are slightly acidic in nature, may not produce any gastric irritation. 


\subsection{Particle Size Analysis}

The particle size analysis is important since it facilitates in understanding the performance of the drug (like it's solubility, dissolution, absorption rate in body, content uniformity, bioavailability, stability, or product appearance $)^{18}$. Herein the surface morphology of the formulations was studied qualitatively using a cold field emission scanning electron microscope (SEM, JSM6701F, Jeol, Japan) ${ }^{19}$. It was carried out in Centre for Advanced Research in Indian System of Medicine (CARISM), SASTRA University, Thanjavur, Tamil Nadu. Results are shown in Figure 1.

\subsection{Crude Fiber Content Analysis}

Acceptable crude fiber consumption has significant health benefits like looking after of healthy laxation and the decrease in the risk of cardiovascular disease ${ }^{20}$. Thus, crude fiber content analysis has been conducted in present research on the formulation under study. The weight of the residue was taken for the calculation of the crude fiber present in the polyherbal formulations. The results are presented in Table 10.

\subsection{Physical Characteristics of Powder Formulation}

The physical characteristics here depict the powder flow aspects. Powder flow is the most important requirement for pharmaceutical manufacturing process. This is because it facilitates in capsules and tablet manufacturing ${ }^{21}$. The physical characteristics of the powder formulation have been conducted by determining bulk density; tap density, angle of response, Hausner ratio and Carr's index. Bulk density of a powder can be defined as "the ratio of the mass of an untapped powder sample and its volume including the contribution of the inter particulate void volume"22. The bulking properties of a powder are reliant on the treatment, preparation, and storage of the sample. Tap density is the at most packing density of a powder reached under the effect of well defined, externally applied forces ${ }^{23}$. It is significant in understanding the compressibility and flow properties of the powder formulation. Carr's Index presents the compressibility of the powder and Hausner ratio presents the flow ability of powder. Finally, angle of response has been calculated. Angle of response is the angle between two bodies (loose material) when upper body is just on the point of sliding. It facilitates in understanding the micro behaviour of the granules ${ }^{24}$. The results are presented in the Table 11.

\subsection{Preliminary Phytochemical Screening}

Phytochemical screening refers to "the extraction, screening and identification of the medicinally active substances found in plants" 25 . Some of the bioactive substances that can be derived from plants have been tested for presence in powder formulation under study in present research through Preliminary Phytochemical screening. The results are tabulated in Table 12.

\subsection{Determination of Safety of Formulation}

In order to determine the associates hazards (if any) associated with the consumption of powder formulation in the present research, following tests were conducted. The analysis was carried out in in TA Labs Pvt. Ltd. Chennai.

\subsection{Heavy Metal Analysis}

Heavy metals are found in nature in the form of elementary compounds or mineral deposits. During the process of extraction and processing, the crude drugs or formulations may come in contact with atmosphere, water, plants, soils and animals, causing toxicity ${ }^{26}$. These collect in the human bodies over a period of time thereby causing severe illness if consumed in trivial quantities. Thus their detection is of at most importance ${ }^{27}$. In the present study, heavy metal determination was conducted by ICP-AES method and the results are presented in Table 13 .

\subsection{Test for Microbial Limits}

Microbial limit test is conducted to assess the viable microbes in the sample that is presence of objectionable $\operatorname{organisms}^{28}$. The microbial limit test for the present research has been conducted as per WHO guidelines of microbial content determination. The results are presented Table 14. 


\subsection{Test for Aflatoxin Determination}

As per WHO, Aflatoxin can be defined as "poisonous substances produced by certain kinds of fungi (moulds) that are found naturally" 29 . These are serious health threats to humans. In the present research, the samples of polyherbal formulation were checked Aflatoxin content with its standard markers, i.e. B1, B2, G1 and G2. The results presented in Table 15 .

\subsection{Test for Pesticide Ratio}

The presence of pesticides in the powder formulation were tested and results are presented in Table 16.

\section{High Performance Thin Layer Chromatography (HPTLC) Fingerprinting of Polyherbal Formulation using Marker Compounds}

1. Selection of Markers

Amla fruit and Acacia bark are rich polyphenols and flavonoids which provide good Antilipidemic effect ${ }^{30-32}$. Further, Gymnemic acid, a pharmacologically active compound in Gymnema sylvestrehas been reported to have Antilipidemic action ${ }^{33,34}$. Finally, Carbazole alkaloid from curry leaves also have Antilipidemic action $^{35}$. Owing to this, the four markers selected are Gallic acid, Quercetin, Gymnemic acid and Mahanine. Details of estimation is given in Table 2.

\section{Results}

The prepared polyherbal formulations were evaluated for organoleptic, physical, physicochemical Parameters. As per organoleptic evaluation the formulations are light brownish green in color, odorless and slight sour in taste. The total ash values, extractive values, moisture content were found to be in limits (as prescribed by API). The results of various physicochemical parameters were tabulated as follows

In the particle size evaluation, SEM image (Figure 1) of the four formulations showed the presence of cluster of small particles placed over smooth planes. PHF1 and PHF3 have got smooth surfaced particle. The size of the particles is ranging from 9.4 to $9.7 \mathrm{~mm}$.

The preliminary phytochemical screening of polyherbal formulations shows the presence of glycosides, alkaloids, saponins, flavonoids and sugars.

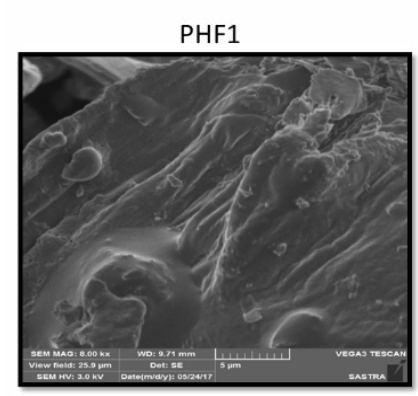

PHF3
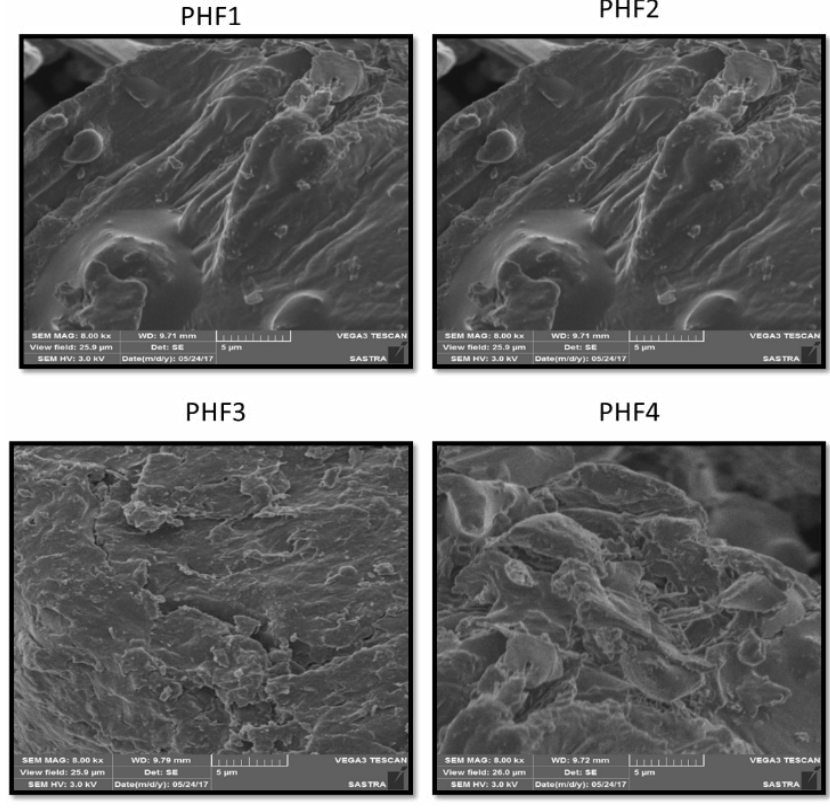

PHF4

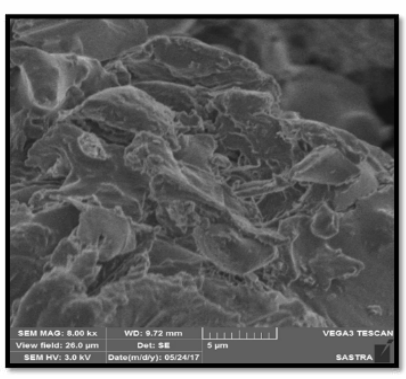

Figure 1. Particle size analysis.

Table 10. Crude fiber analysis results

\begin{tabular}{cc}
\hline Formulations & Crude Fiber $(\% \mathbf{w} / \mathbf{w})$ \\
\hline PHF 1 & $7.71 \pm 0.18$ \\
PHF 2 & $6.36 \pm 0.53$ \\
PHF 3 & $7.14 \pm 0.23$ \\
PHF4 & $6.64 \pm 0.28$ \\
\hline
\end{tabular}

Table 11. The physical characteristics of the powder formulation

\begin{tabular}{llllll}
\hline Formulations & Angle of repose & Bulk density (\%) & Tapped density (\%) & Carr's Index & Hausner ratio \\
\hline PHF 1 & $45.64 \pm 0.06$ & $0.31 \pm 0.003$ & $0.36 \pm 0.02$ & 21.282 & 1.27 \\
PHF 2 & $45.61 \pm 0.06$ & $0.30 \pm 0.003$ & $0.38 \pm 0.006$ & 21.282 & 1.27 \\
PHF 3 & $45.62 \pm 0.07$ & $0.31 \pm 0.003$ & $0.38 \pm 0.03$ & 21.282 & 1.27 \\
PHF 4 & $45.60 \pm 0.04$ & $0.31 \pm 0.003$ & $0.37 \pm 0.03$ & 21.282 & 1.27 \\
\hline
\end{tabular}


The physical characteristic study of the powder formulation showed that the flow ability of the formulations was found to be possible to flow.

Table 12. Preliminary phytochemical screening

\begin{tabular}{ccccc}
$\begin{array}{c}\text { Chemical } \\
\text { constituent }\end{array}$ & PHF 1 & PHF 2 & PHF 3 & PHF 4 \\
\hline Glycosides & $+\mathrm{ve}$ & $+\mathrm{ve}$ & $+\mathrm{ve}$ & $+\mathrm{ve}$ \\
Alkaloids & $+\mathrm{ve}$ & $+\mathrm{ve}$ & $+\mathrm{ve}$ & $+\mathrm{ve}$ \\
Tannin & $+\mathrm{ve}$ & $+\mathrm{ve}$ & $+\mathrm{ve}$ & $+\mathrm{ve}$ \\
Saponins & $+\mathrm{ve}$ & $+\mathrm{ve}$ & $+\mathrm{ve}$ & $+\mathrm{ve}$ \\
Sugars & $+\mathrm{ve}$ & $+\mathrm{ve}$ & $+\mathrm{ve}$ & $+\mathrm{ve}$ \\
Flavonoid & $+\mathrm{ve}$ & $+\mathrm{ve}$ & $+\mathrm{ve}$ & $+\mathrm{ve}$ \\
Fixed oil & -ve & $-\mathrm{ve}$ & $-\mathrm{ve}$ & -ve \\
\hline
\end{tabular}

Table 13. Heavy metal analysis

\begin{tabular}{lcccc}
\hline $\begin{array}{c}\text { Formu } \\
\text { lations }\end{array}$ & $\begin{array}{c}\text { Lead } \\
\mathbf{( P b )} \\
\mathbf{P p m}\end{array}$ & $\begin{array}{c}\text { Arsenic } \\
\text { (As) } \\
\mathbf{p p m}\end{array}$ & $\begin{array}{c}\text { Mercury } \\
\mathbf{( H g )} \\
\mathbf{p p m}\end{array}$ & $\begin{array}{c}\text { Antimony } \\
\text { (Sb) ppm }\end{array}$ \\
\hline PHF 1 & 2.26 & $\mathrm{BDL}$ & $\mathrm{BDL}$ & $\mathrm{BDL}$ \\
PHF 2 & $\mathrm{BDL}$ & $\mathrm{BDL}$ & $\mathrm{BDL}$ & $\mathrm{BDL}$ \\
PHF 3 & $\mathrm{BDL}$ & $\mathrm{BDL}$ & $\mathrm{BDL}$ & $\mathrm{BDL}$ \\
PHF 4 & $\mathrm{BDL}$ & $\mathrm{BDL}$ & $\mathrm{BDL}$ & $\mathrm{BDL}$ \\
\hline
\end{tabular}

In the table, BDL is "below detectable limit"

Heavy metals analysis includedthe evaluation of antimony, lead, arsenic and mercury. The results were within limits.

All the four polyherbal formulations were devoid of aflatoxin and pesticide content.

The results of Marker based analysis of four polyherbal formulations shown in Table 17, Figures 2-5.

\section{Discussion}

The present study has been focused to standardize the traditional polyherbal medicine by subjecting it through various physical, chemical tests. It was evaluated for organoleptic, physical, physicochemical tests. The total ash values, extractive values, moisture content were found to be in limits (as prescribed by API). The $\mathrm{pH}$ value was determined to avoid gastric irritation. The moisture content was measured to find any increase in weight caused by moisture contamination.

The determination of crude fiber content is an indicative of fiber content in formulations. Phytochemical screening was carried out, shows the

Table 14. Microbial limit test

\begin{tabular}{ccccc}
\hline Parameters & PHF 1 & PHF 2 & PHF 3 & PHF 4 \\
\hline Staphylococcus aureus & Absent & Absent & Absent & Absent \\
Salmonella species & Absent & Absent & Absent & Absent \\
Pseudomonas aeruginosa & Absent & Absent & Absent & Absent \\
E coli & Absent & Absent & Absent & Absent \\
Total bacterial count.(TBC) & $37000 \mathrm{CFU/g}$ & $37000 \mathrm{CFU/g}$ & $37000 \mathrm{CFU/g}$ & $37000 \mathrm{CFU} / \mathrm{g}$ \\
Total fungal count.(TFC) & $220 \mathrm{CFU/g}$ & $220 \mathrm{CFU} / \mathrm{g}$ & $220 \mathrm{CFU} / \mathrm{g}$ & $220 \mathrm{CFU/g}$ \\
\hline
\end{tabular}

The results of microbial test were found to be within the limit

Table 15. Aflatoxin determination test

\begin{tabular}{ccccc}
\hline Parameters & PHF 1 & PHF 2 & PHF 3 & PHF 4 \\
\hline Aflatoxin (B 1) & BLQ & BLQ(LOQ:0.5 g/kg) & BLQ(LOQ:0.5 g/kg) & BLQ(LOQ:0.5 g/kg) \\
Aflatoxin (B 2) & BLQ(LOQ:0.5 g/kg) & BLQ & BLQ & BLQ \\
Aflatoxin (G 1) & BLQ & BLQ & BLQ & BLQ \\
Aflatoxin (G 2) & BLQ & BLQ & BLQ & BLQ
\end{tabular}

BLQ- Below the limit of quantification 
Table 16. Pesticide ratio

\begin{tabular}{|c|c|c|c|c|}
\hline Parameters & PHF 1 & PHF 2 & PHF 3 & PHF 4 \\
\hline Organo- phosphorous pesticides & BLQ (DL:10 $\mu \mathrm{g} / \mathrm{kg})$ & BLQ (DL:10 $\mu \mathrm{g} / \mathrm{kg})$ & BLQ (DL:10 $\mu \mathrm{g} / \mathrm{kg})$ & BLQ (DL:10 $\mu \mathrm{g} / \mathrm{kg})$ \\
\hline Organo-chlorine pesticides & BLQ (DL:10 $\mu \mathrm{g} / \mathrm{kg})$ & BLQ (DL:10 $\mu \mathrm{g} / \mathrm{kg})$ & BLQ (DL:10 $\mu \mathrm{g} / \mathrm{kg})$ & BLQ (DL:10 $\mu \mathrm{g} / \mathrm{kg})$ \\
\hline
\end{tabular}

BLQ- Below the limit of quantification

Table 17. Evaluation of Simultaneous HPTLC Analysis for the Four Markers

\begin{tabular}{|c|c|c|c|}
\hline Quercetin & Gallic Acid & Gymnemic acid & Mahanine \\
\hline $\begin{array}{c}\text { The samples PHF1, PHF2, PHF3 } \\
\text { and PHF4 were subjected to } \\
\text { HPTLC analysis using Quercetin } \\
\text { standard (Figure } 2 \mathrm{~b} \text { ) with Rf value } \\
0.60 \text {. } \\
\text { The formulations presented Rf } \\
\text { values } 0.61,0.66,0.62 \text { and } 0.60 \\
\text { with } \% \text { area of } 10.93,10.60 \text {, } \\
15.88 \text { and } 16.07 \text { respectively for } \\
\text { Quercetin standard. (Figure } 3 \mathrm{a}, \mathrm{b} \text {, } \\
\text { c, d respectively) }\end{array}$ & $\begin{array}{c}\text { The samples PHF1, PHF2, } \\
\text { PHF3 and PHF4 were } \\
\text { subjected to HPTLC analysis } \\
\text { using Gallic acid standard } \\
\text { (Figure } 2 \mathrm{a} \text { ) with Rf value } \\
0.43 \text {. } \\
\text { For analysis using Gallic acid } \\
\text { as standard formulations } \\
\text { showed Rf values } 0.47,0.49 \text {, } \\
0.45 \text { and } 0.44 \text { with } \% \text { area of } \\
68.89 \%, 83.20 \%, 57.48 \% \text { and } \\
59.54 \% \text { respectively. (Figure } \\
3 \text { a, b, c, d respectively) }\end{array}$ & $\begin{array}{c}\text { A band at Rf value of } \\
0.44 \text { corresponding to } \\
\text { Gymnemic acid (Figure } 2 \mathrm{c} \text { ) } \\
\text { can be seen to bevisible in } \\
\text { test solution tracks (PHF1 to } \\
\text { PHF4). }\end{array}$ & $\begin{array}{l}\text { A band at Rf value of } 0.89 \\
\text { corresponding to Mahanine } \\
\text { is visible in test solution } \\
\text { track. }\end{array}$ \\
\hline $\begin{array}{l}\text { The HPTLC analysis presented } \\
\text { a \% area of } 16.07 \text { Quercetin } \\
\text { equivalents for PHF4. } \\
\text { Thus, it can be stated that out of } \\
\text { the four formulations, PHF2 has } \\
\text { greater amount of Quercetin. }\end{array}$ & $\begin{array}{c}\text { The HPTLC analysis } \\
\text { presented a \% area of } 83.20 \\
\text { Gallic acid equivalent for } \\
\text { PHF2. } \\
\text { Thus, it can be stated that } \\
\text { out of the four formulations, } \\
\text { PHF4 has greater amount of } \\
\text { Gallic acid. }\end{array}$ & $\begin{array}{l}\text { On comparing with } \\
\text { standard Gymnemic acid, } \\
\text { PHF2 (Figure 4b) has got } \\
\text { significant amount of } \\
\text { Gymnemic acid ( } 23.15 \%) \\
\text { while other samples } \\
\text { displayed very less amount } \\
\text { for formulations PHF1 } \\
\text { (6.46\%), PHF3 (7.39\%) and } \\
\text { PHF4 (11.34\%) (Figure } 4 \text { a, c } \\
\text { and d) respectively. }\end{array}$ & $\begin{array}{c}\text { On comparing with standard } \\
\text { Mahanine (Figure 16), PHF1 } \\
\text { (Figure 5a) found to have } \\
\text { more Mahanine content } \\
\text { (58.30\%) than PHF2 (Figure } \\
5 \mathrm{~b} \text { ) and PHF3 (Figure } 5 \mathrm{c} \text { ) } \\
\text { that is } 12.78 \% \text { and } 13.56 \% \\
\text { respectively. PHF4 (Figure } \\
5 \mathrm{~d} \text { ) does not contain } \\
\text { significant amount of } \\
\text { Mahanine }\end{array}$ \\
\hline \multicolumn{2}{|c|}{$\begin{array}{l}\text { Thus, the polyherbal formulation prepared by using raw } \\
\text { materials collected during rainy seasons may have more } \\
\text { amount of active constituent. Thus, it can be stated that it may } \\
\text { have more therapeutic value compared to other formulations. }\end{array}$} & $\begin{array}{l}\text { Thus, the formulation } \\
\text { prepared by using herbals } \\
\text { collected during monsoon } \\
\text { season (PHF2) has got more } \\
\text { amount of Gymnemic acid. }\end{array}$ & $\begin{array}{l}\text { Thus, the formulation } \\
\text { prepared by using herbals } \\
\text { collected during, summer } \\
\text { season (PHF 1) having } \\
\text { maximum Mahanine } \\
\text { content. }\end{array}$ \\
\hline
\end{tabular}

presence of flavonoids, tannins, alkaloids, glycosides, sugars and Saponins.

The physical characteristics of the powder formulation shows that the flow ability of the formulations were found to be possible to flow.

Herbal formulations are liable to contaminated with heavy metals such as, lead, cadmium, arsenic and mercury. Heavy metals present in Polyherbal formulations will have a toxic effect on different organs of body in particularly in kidneys, leads to renal failure. So evaluation of heavy metals is very important. Heavy metals tests included cadmium, lead, arsenic and lead. The results were within limits.

Herbal drugs may also be contaminated with microbial content and various pesticide residues, which accumulated from various agricultural procedures, or from atmosphere, may be from soil or by use of different pesticide agents. The current practice of production and harvesting technology affect the health of consumer. So it is very important to evaluate the presence of pesticide residues. Particularly Aflatoxin content needs special attention which may lead to serious side effect, 

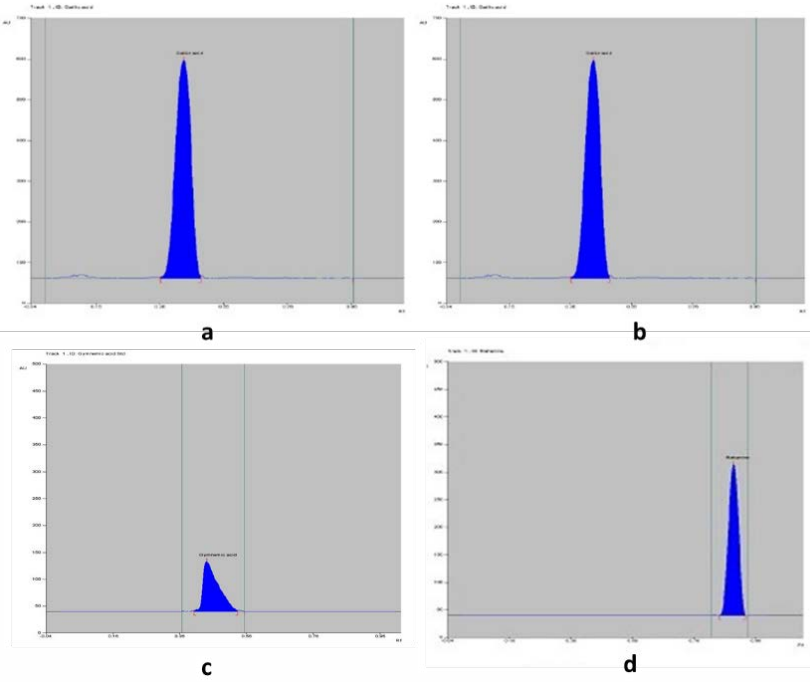

Figure 2. (a) Standard Gallic Acid solution, (b) Standard solution Quercetin, (c) Standard solution Gymnemic Acid, (d) Standard solution Mahanine.
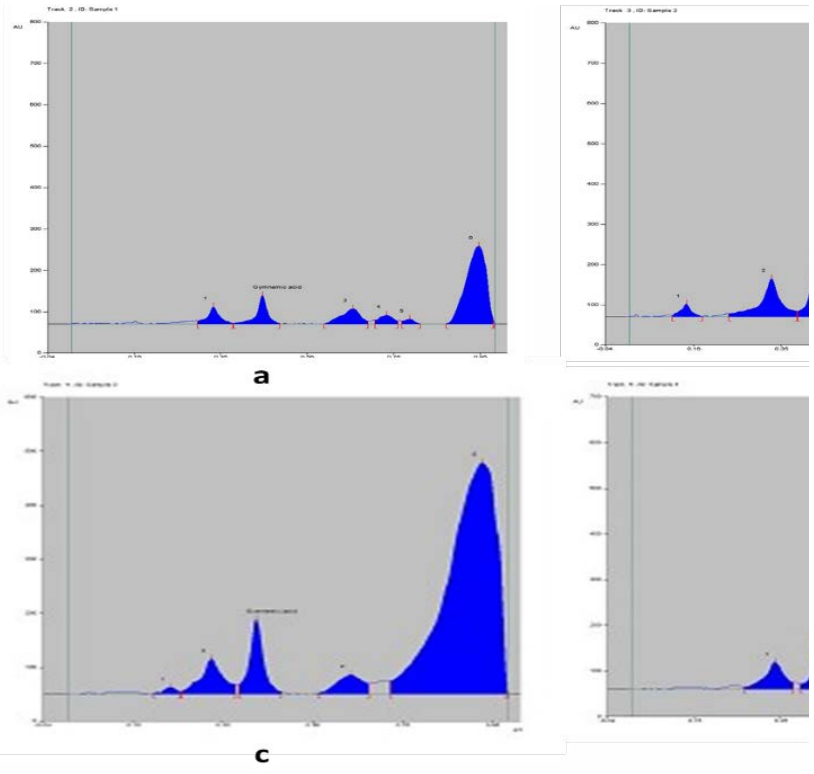

Figure 4. (a) PHF1, (b) PHF2, (c) PHF3, (d) PHF4 with gymnemic acid

if it is present in formulation ${ }^{38}$. To overcome this toxic effect WHO recommended certain regulation to limit heavy metal content, pesticide content, and microbial content. As per regulation, Aflatoxin content should not be present in the formulation. The present study did not found any Aflatoxins and pesticide residues in the formulations.
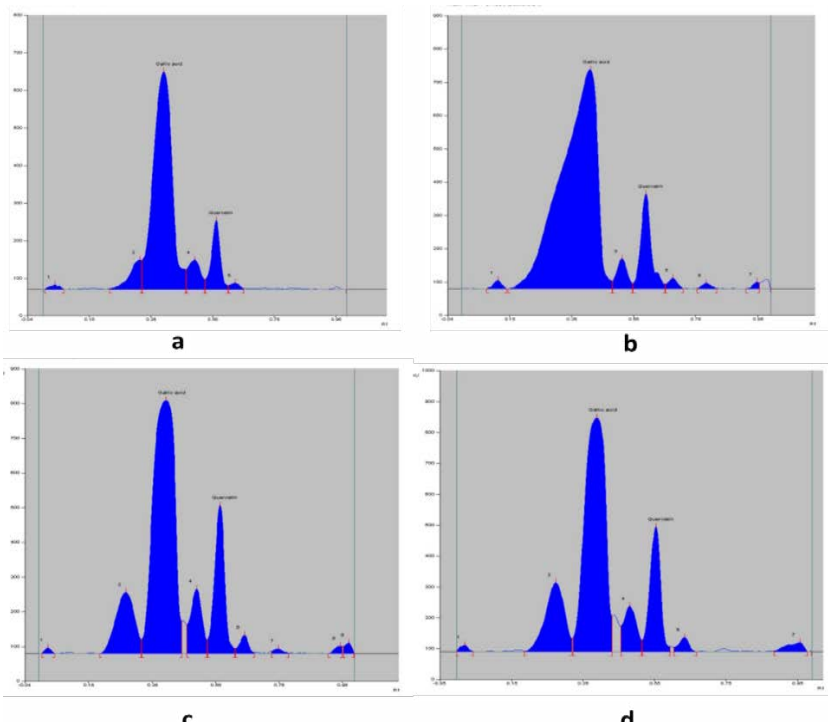

Figure 3. (a) PHF1, (b) PHF2, (c) PHF3, (d) PHF4 with quercetin and gallic acid.
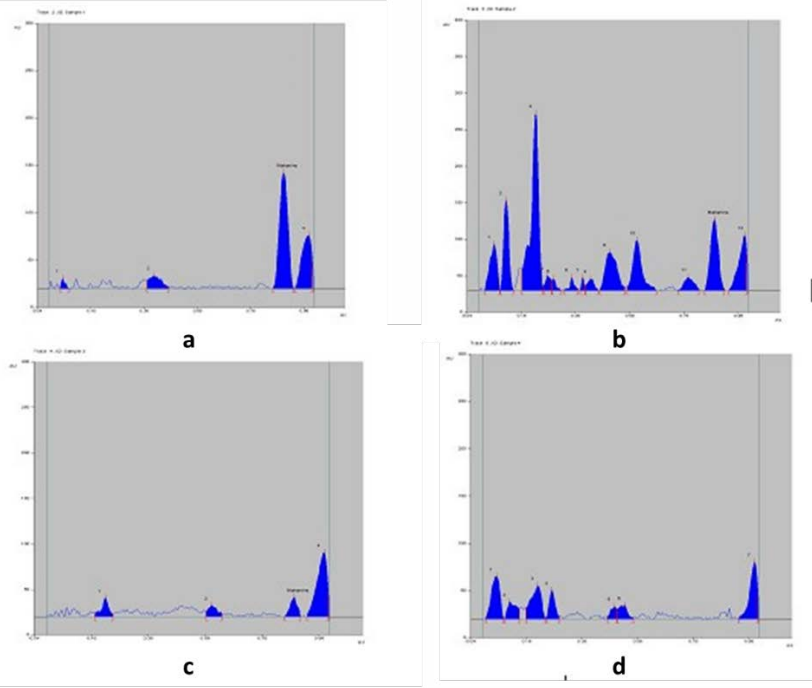

Figure 5. (a) PHF1, (b) PHF2, (c) PHF3, (d) PHF4 with Mahanine.

For HPTLC marker base analysis, Gallic Acid, Quercetin, Gymnemic Acid and Mahanine were used as markers for Amla, Acacia, Gymnema and Curry leaves respectively. The results stated thatthe content of markerswere found to be maximum in rainy season as compared to summer season (exceptfor the case of curry leaves). In case of Amla and Acacia, PHF2 showed presence of greater amount of Quercetin (16.07\%) and PHF4 showed greater amount of Gallic acid (83.20\%). Both the ingredients were collected in rainy season 
from Malappuram and Gudallore respectively. In case of Gymnema Formulation, PHF2 showed significant amount of Gymnemic acid (23.15\%), along with PHF4 (11.34\%) while other samples presented very less amount (6.46\% and 7.39\%) for PHF1and PHF3 respectively. So, the herbs collected during monsoon season showed presence of more amounts of active constituents when compared withmarkers. But in case of Curry leaves, HPTLC analysis revealed that the content of Mahanine is maximum in summer season and very negligible in rainy season wherein PHF1 had maximum content (58.30\%)followed by PHF3 (13.56\%) compared to other two formulations (PHF2 and PHF4).

Thus, in this case it can be stated that the traditional polyherbal medicine prepared by using raw materials collected during rainy seasons may have more amount of active constituent owing to which it might have more therapeutic values.

\section{Conclusion}

The polyherbal formulation for curing hyperlipidemia was evaluated based on standard evaluation parameters (as per API and WHO standards). As per holistic approach of Ayurveda, Polyherbal formulations which are used for curing different disease conditions, contains various phyto-constituents and herbal drug combinations. These drugs work together to produce to synergistic effect for desired therapeutic action. The present research was based on standardizing a polyherbal formulation for treating hyperlipidemia. The study found that there is a change in content of phyto-constituents of same drugs which are collected from different areas and in different seasons. These changes also affect the therapeutic efficacy of polyherbal formulations.

\section{Acknowledgements}

The authors are thankful to VIT University Vellore, Tamil Nadu and Al Shifa College of Pharmacy, Malappuram Dist. Kerala for providing all the facilities for this study.

\section{References}

1. Shattat GF. A review article on hyperlipidemia: Types, treatments and new drug targets. Biomedical and Pharmacology Journal. 2014; 7(2):399-409. https://doi.org/10.13005/ bpj/504

2. Ahmed A, Mustofa MJ. Role of soft law in environmental protection: An overview. Global Journal of Politics and Law Research. 2016; 4(2):1-18.

3. Smith TC. The neomuran origin of archaebacteria, the negibacterial root of the universal tree and bacterial megaclassification. International Journal of Systamatic and Evolutionary Microbiology. 2002; 52(1):7-76. https://doi. org/10.1099/00207713-52-1-7. PMid:11837318

4. Society for Vascular Surgery. Hyperlipidemia [Internet]. [cited 2019 Nov 10]. Available from: https//vascular.org/ patient-resources/vascular-conditions/hyperlipidemia.

5. Kramer W. Antilipidemic drug therapy today and in the future. Handbook of Experimental Pharmacology. 2015 :251-63. https://doi.org/10.1007/164_2015_15. PMid:26330256 PMCid:PMC7122375

6. Collins R, Reith C, Emberson J, Armitage J, Baigent $\mathrm{C}$, Blackwell $\mathrm{L}$ et al. Interpretation of the evidence for the efficacy and safety of statin therapy. Lancet. 2016; 388(10059):2532-61. https://doi.org/10.1016/S01406736(16)31357-5

7. Meeusen JW, Donato LJ, Jaffe AS. Should apolipoprotein $B$ replace LDL cholesterol as therapeutic targets are lowered? Current Opinion in Lipidology. 2016; 27(4):359-66. https://doi.org/10.1097/MOL.0000000000000313. PMid:27389631

8. Brown JM. No foie gras with apolipoprotein B inhibitors? Science Translational Medicine. 2016; 8(357). https://doi. org/10.1126/scitranslmed.aah7024

9. Dhrubajyoti B, Ashish K, Adrija H, Arshna Q, K. Ghosh R. Science Translational Medicine. Journal of Lipids. 2018:113. https://doi.org/10.1155/2018/3179201. PMid:29770231 PMCid:PMC5889852

10. Hernáez Á, Castañer O, Elosua R, Pinto X, Estruch R, Salas-Salvado J, et al. Mediterranean diet improves highdensity lipoprotein function in high-cardiovascular-risk individuals. Circulation. 2017; 135(7):633-43. https:// doi.org/10.1161/CIRCULATIONAHA.116.023712. PMid:28193797

11. Ko DT, Alter DA, Guo H, Koh M, Lau G, Austin PC, et al. High-density lipoprotein cholesterol and cause-specific mortality in individuals without previous cardiovascular conditions: The CANHEART study. Journal of American College of Cardiology. 2016; 68(19):2073-83. https://doi. org/10.1016/j.jacc.2016.08.038. PMid:27810046

12. Canfrán-Duque A, Lin CS, Goedeke L, Suárez Y, FernándezHernando C. Micro-RNAs and high-density lipoprotein 
metabolism. Arteriosclerosis Thrombosis Vascular Biology. 2016; 36(6):1076-84. https://doi.org/10.1161/ATVBAHA.1 16.307028. PMid:27079881 PMCid:PMC5315356

13. Karole S, Shrivastava S, Thomas S, Soni B, Khan S, Dubey S, et al. Polyherbal Formulation Concept for Synergic Action: A Review. Journal of Drug Delivery and Therapeutics. 2019; 9(1). https://doi.org/10.22270/jddt.v9i1-s.2339

14. Martins E. The growing use of herbal medicines: Issues relating to adverse reactions and challenges in monitoring safety. National Centre for Biotechnology Information. 2014; 4. https://doi.org/10.3389/fphar.2013.00177. PMid:24454289 PMCid:PMC3887317

15. Ekka N, Nmedo K. Standardization strategies for herbal drugs. Research Journal of Pharmacy and Technology. 2008; 1:301-12.

16. Bhargava VV, Saluja AK, Dholwani KK. Detection of heavy metal contents and proximate analysis of roots of Anogeissus latifolia. Journal of Pharmacognosy and Phytochemistry. 2013; 1(6):61-5.

17. Manallack DT, Prankerd RJ, Yuriev E, Oprea TI, Chalmers DK. The Significance of acid/base properties in drug discovery. National Centre for Biotechnology Information. 2014; 42(2):485-96. https://doi.org/10.1039/C2CS35348B. PMid:23099561 PMCid:PMC3641858

18. Sun Z, Ya N, Adams RC, Fang FS. Particle size specifications for solid oral dosage forms: A regulatory perspective. American Pharmaceutical Review. 2010; 13(4).

19. Rajalakshmi P, Sudeer RG, Vadivel V, Sahayam CS, Brindha P. Analytical studies on Annabethi Chenthuram, A Siddha Herbomineral Formulation. Indian Journal of Pharmaceutical Science. 2017; 79(6):987-93. https://doi. org/10.4172/pharmaceutical-sciences.1000316

20. Madhu C, Krishna KM, Reddy KR, Lakshmi PJ, Eswar KK. Estimation of crude fibre content from natural food stuffs and its laxative activity induced in rats. International Journal of Pharma Research and Health Science. 2017; 5(3):1703-6. https://doi.org/10.21276/ijprhs.2017.03.04

21. Shah RB, Tawakkul MA, Khan MA. Comparative evaluation of flow for pharmaceutical powders and granules. National Centre for Biotechnology Information. 2008; 9(1):250-8. https://doi.org/10.1208/s12249-008-9046-8. PMid:18446489 PMCid:PMC2976911

22. Gaikwad A, More N, Wele A. Bulk density and tapped density of powders. International Journal of Ayurveda Pharma Research. 2015; 3(10):2322-902.

23. Thomas MA. Importance of powder density in solid dosage form [Internet]. 2019 [cited 2019 Nov 24]. Available from: https://www.pharmaceuticalonline.com/doc/importanceof-powder-density-in-solid-dosage-0001.
24. Al-Hashemi HMB, Al-Amoudi OSB. A review on the angle of repose of granular materials. Elsevier. 2018; 330:397-417. https://doi.org/10.1016/j.powtec.2018.02.003

25. Insight Medical Publishing. Phytochemical screening [Internet]. 2019 [cited 2019 Nov 24]. Available from: http:// www.imedpub.com/scholarly/phytochemical-screeningjournals-articles-ppts-list.php.

26. Kulkarni NM. Detection of heavy metals in azathiorpine api drugs. International Journal of Chemical Physics Science. 2018; 7(3):88. https://doi.org/10.30731/ijcps.7.3.2018.88-91

27. Tchounwou P, Yedjou C, Patlolla A, Sutton D. Heavy metal toxicity and the environment. National Centre for Biotechnology Information. 2012; 101:133-64. https:// doi.org/10.1007/978-3-7643-8340-4_6. PMid:22945569 PMCid:PMC4144270

28. Pacific BioLabs. Microbial Limits Test. [Internet]. 2019 [cited 2019 Nov 24]. Available from: https://pacificbiolabs. com/microbial-limits-testing.

29. Department of Food Safety and Zoonoses. Aflatoxins; 2018.

30. Gopa B, Bhatt J, Hemavathi KG. A comparative clinical study of hypolipidemic efficacy of Amla (Emblica officinalis) with 3-hydroxy-3-methylglutaryl-coenzyme-A reductase inhibitor simvastatin. Indian Journal of Pharmacology. 2012; 44(2):238-42. https://doi.org/10.4103/0253-7613.93857. PMid:22529483 PMCid:PMC3326920

31. Lama A, Saikia H. The effects of Emblica officinalis on serum lipids and atherogenesis, in albino rats fed with high fat diet. International Journal Pharma Professionals Research. 2011; 2(2).

32. Ikarashi N, Toda T, Okaniwa T, Ito K, Ochiai W, Sugiyama K. Anti-obesity and anti-diabetic effects of acacia polyphenol in obese diabetic KKAy mice fed high-fat diet. EvidenceBased Complementary and Alternative Medicine. 2011. https://doi.org/10.1093/ecam/nep241. PMid:21799697 PMCid:PMC3137845

33. Kirtikar K, Basu B. Indian medicinal plants - III. 3rd ed. Dehradun, India: International Book Distributors; 1998.

34. Kapoor LD. Handbook of Ayurvedic Medicinal Plants: Herbal Reference Library. 1st ed. CRC Press, Taylor \& Francis Group; 2000.

35. Dineshkumar B, Mitra A, Mahadevappa M. Antidiabetic and Hypolipidemic Effects of Mahanimbine (Carbazole Alkaloid) From Murraya Koenigii (Rutaceae) Leaves. International Journal of Phytomedicine. 2010; 2(1).

36. Tandon N, Sharma P. Quality Standards of Indian Medicinal Plants. 3rd ed. Indian Council of Medical Research; 2005.

37. Wagner H, Bladt S, Zgainski EM. Plant drug analysis - a thin layer chromatography atlas. New York: Springer; 1986. doi.org/10.1002/jobm.3620260220.

38. Basu BD, Kirtikar KR. Indian Medicinal Plants. New Delhi: Periodical Experts Book Agenc; 2012. 